In this issue:

Call for Papers

for ACRL National Conference

Folger Library Acquires

Reformation Editions

News from the Field

People

Publications

Classified Advertising

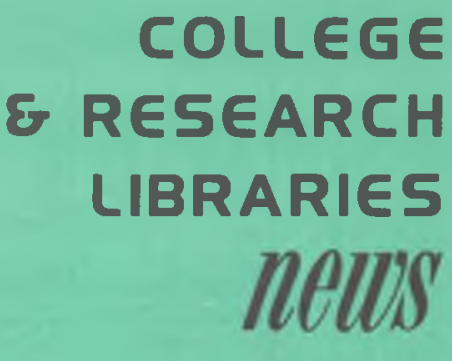

NO. 9 OCTOBER 1977

\title{
Call for Papers for ACRL National Conference: New Horizons for Academic Libraries
}

November $8-11,1978$

Sheraton-Boston Hotel

Boston, Massachusetts

The Association of College and Research Libraries, a division of the American Library Association, will present its first national conference in Boston, Massachusetts, November 8-11, 1978.

The conference will focus on the future prospects for academic and research librarianship in the United States. There will be a variety of program meetings, exhibits by publishers and library equipment suppliers, special functions at other area institutions, and organized tours to visit various libraries in the greater Boston area. The conference will be held in the Sheraton-Boston Hotel, centrally located in Boston's Prudential Center.

A major feature of the conference will be the sessions for contributed papers. These papers

Notice of Intent to Submit

Submission of Completed Manuscript

Notification of Acceptance should relate broadly to the major theme of the conference-the future of academic and research librarianship. Possible topics include, but are not limited to, the following:

-Administration and Management of $\mathrm{Li}$ braries

-Economic Support for Libraries

-Technology and Libraries

- Cooperation and Networking

-The Role of the Library in the College and the University

-The Role of the Academic Librarian

-Resources and Services

All submitted papers will be refereed (with authors' names removed), and those accepted will be scheduled for presentation at the conference. Authors must be present to deliver their papers. Authors who plan to submit papers may use the form on page 265 (or a copy of $\mathrm{it}$ ), and they will receive instructions for preparing their manuscripts. The conference will observe the deadlines given below.

November 30, 1977

February 28, 1978

May 31, 1978

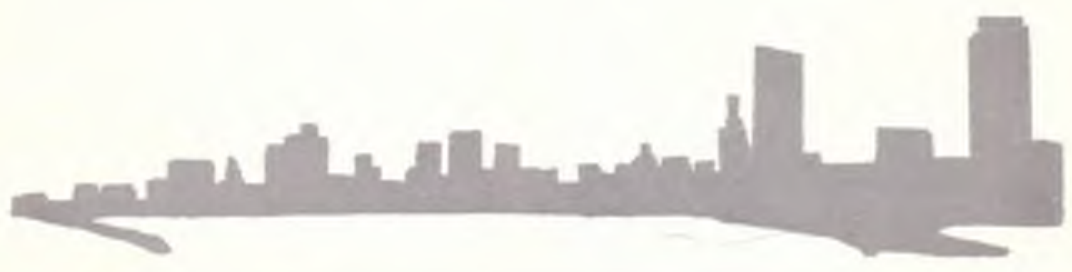

News issue (B) of College \& Research Libraries, vol. 38, no. 5 

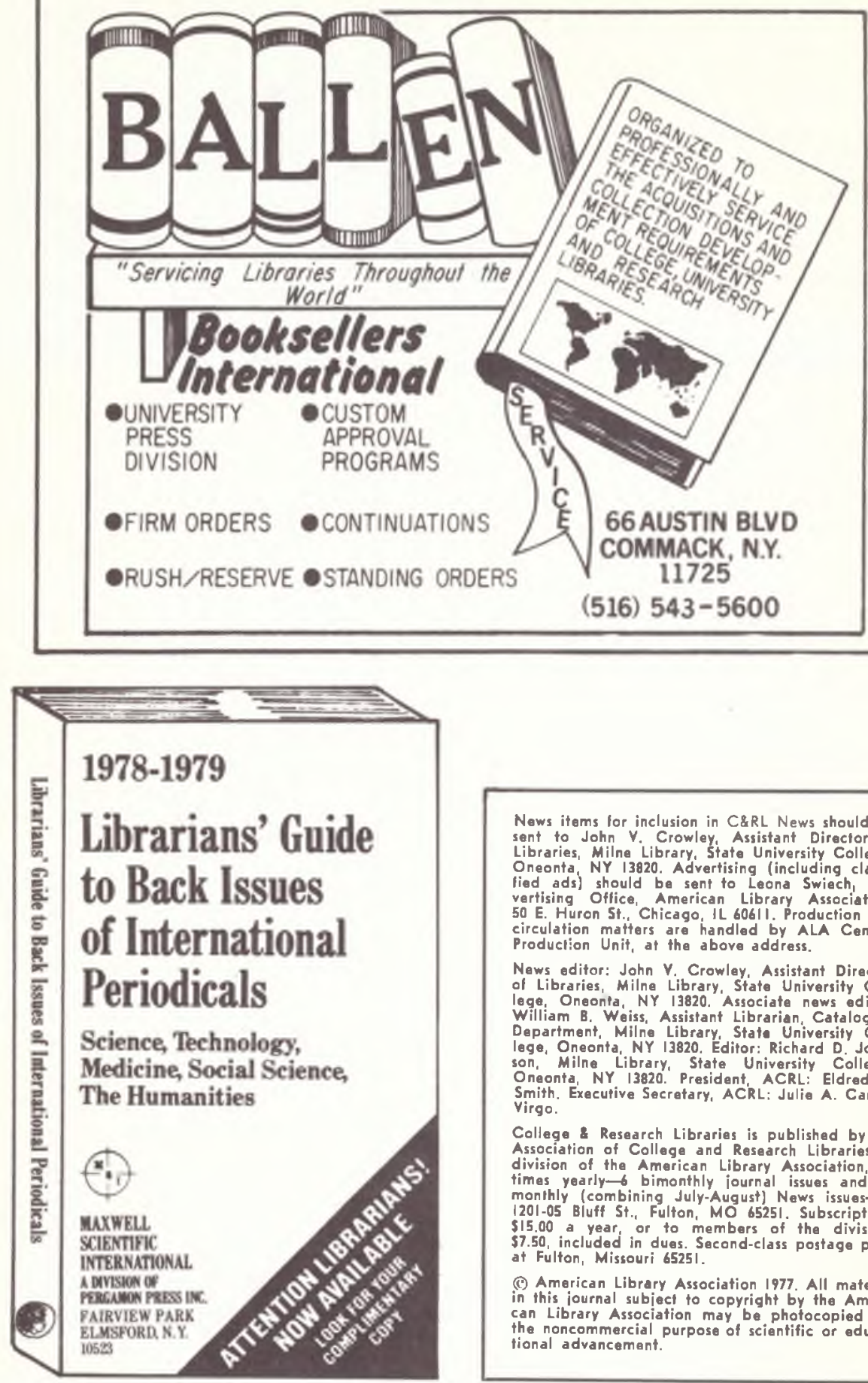

News items for inclusion in C\&RL News should be sent to John $Y$. Crowley Assistant Director of Libraries, Milne Library, State University College Oneonta, NY 13820. Advertising (including classified ads) should be sent to Leona Swiech, Advartising Office, American Library Association. 50 E. Huron St. Chicago IL 60611 Production and eireulation matters are handled by ALA Central Production Unit, at the above address.

News editor: John V. Crowley, Assistant Director of Libraries, Milne Library, State University College. Oneonla, NY 13820. Associate news editor, William B. Weiss, Assistant Librarian Cataloging Department, Milne Library, State University College, Oneonta, NY 13820. Editor: Richard D. Johnson, Milne Library, State University College. Oneonta NY 13820. President ACRL: Eldred R. Smith. Execupive Secretary, ACRL: Julie A. Carroll Virgo.

College : Research Libraries is published by the Association of College and Research Libraries, a division of the American Library Association, 17 times yearly $\rightarrow$ bimonthly journal issues and II monthly (combining July-August) News issues $\rightarrow$ t 1201-05 Bluff St., Fulton, MO 65251. Subscription, $\$ 15.00$ a year, or to members of the division. $\$ 7.50$, included in dues. Second-class postage paid at Fulton, Missouri 65251.

(1) American Library Association 1977 . All materia in this journal subject to copyright by the American Library Association may be photocopied for the noncommercial purpose of scientific or educational advancement. 